Annals of Warsaw University of Life Sciences - SGGW

Land Reclamation No 47 (4), 2015: 333-342

(Ann. Warsaw Univ. of Life Sci. - SGGW, Land Reclam. 47 (4), 2015)

\title{
Hydromorphological and landscape valorization of the Poprad river valley
}

\author{
MARIA NAWIEŚNIAK ${ }^{1}$, MATEUSZ STRUTYŃSKI ${ }^{2}$, JÓZEF HERNIK ${ }^{1}$ \\ ${ }^{1}$ Department of Land Management and Landscape Architecture \\ ${ }^{2}$ Department of Hydraulic Engineering and Geotechnics \\ University of Agriculture in Krakow
}

\begin{abstract}
Hydromorphological and landscape valorization of the Poprad river valley. The paper presents the results of hydromorphological and landscape valorization. The research was carried out in the Valley of the Poprad River, in the section from Piwniczna-Zdrój to Rytro (Małopolska voivodship). The hydromorphological valorization was made using the method of the evaluation of hydromorphological quality of the river. ECOVAST method was used for landscape valorization. On the basis of the research, Authors concluded that the research area is characterized by considerable hydromorphological variability, in particular in relation to the floodplains terraces and their connectivity with the main channel of the river. At the same time the valley of the Poprad river is characterized by the landscape of regional significance, with a very large tourist potential.
\end{abstract}

Key words: hydromorphological valorization, ECOVAST method, landscape identification, Poprad river valley

\section{INTRODUCTION}

The valleys of the river are ecological channels with a very high biodiversity and habitats for a lot of species. These valleys are also a key element of the landscape (Kałamucka 2007). The changes taking place in their area, even those that concern only river channel, have an impact on the structure of the whole landscape.
Poland as a Member of the European Union ratified among others Water Framework Directive (WFD 2000) and European Landscape Convention (ELC 2000). The one of the most important tasks of water management, according to WFD (2000) is preventing water pollution and get all EU waters in good ecological condition by the end of 2015 . Biological, physico-chemical quality elements, supported by hydromorphological quality elements determine the good ecological condition of surface water (WFD 2000).

According to ELC (2000), legal status should be given to the landscape and it should be considered as a basis for: the quality of life, shape of the regional and local awareness and of the implementation of natural and cultural diversity. There should be also guaranteed protection, management and planning of landscape, no matter if it is natural, cultural, urban, degraded, characterized by unique beauty, or if it belongs to "everyday" landscapes (Stoeglehner and Schmid 2007).

Currently, in the valuable landscapes areas, there may appear a problem, for appropriate and responsible management. 
The presence of valuable cultural landscapes should not restrict, prevent or hinder the economic utilization of these areas (Hernik 2008). However, those areas cannot be subjected to uncontrolled appropriating. So far, the treatments, which have affected the landscape, especially in Polish rural communities, were often carried out in an uncoordinated manner (Hernik et al. 2013). Decisions about their adoption were mostly random and often reflecting various interests of small groups. An assessment and landscape identification should be performed to meet the benchmarks of ELC (2000).

The aim of this paper is to present the hydromorphological and landscape valorization in the section of the Poprad river, and to identify most valuable landscapes and hydromorphological areas.

\section{MATERIAL AND METHODS}

The Poprad river flows through the north-eastern Slovakia and southern Poland through Beskid Sądecki (Małopolska voivodship), and enters to Dunajec river in $112+600 \mathrm{~km}$, as a right tributary. The spring of the Poprad river is located in Great Hińczowski Pond. Hińczowski Stream that originates in the spring flows in the Slovak part of the High Tatras. The length of the whole river is $170 \mathrm{~km}$, in Poland $-62.6 \mathrm{~km}$ (including sections located at the border $-30.5 \mathrm{~km}$ ). The Poprad river basin area is $2,077 \mathrm{~km}^{2}$, in Poland $-483 \mathrm{~km}^{2}$ (Kobiela et al. 2012). The Poprad river is a mountain river, characterized by sudden spates and dynamic fluvial processes.

The valley of the Poprad river along its entire length is characterized by unique landscape and ethnographic values. The villages located along this river are further characterized by spa resorts, tourist and historical values. Currently, the valley of the Poprad river on the Polish side is protected, as a part of the Popradzki Landscape Park. This park was created in 1987 on over 54 thousand ha (Wiśniowska-Węglarz 2008).

Hydromorphological and landscape valorization was made in the valley of the Poprad river, in the section from Piwniczna-Zdrój ( $\mathrm{km} \mathrm{20+650)}$ to Rytro $(\mathrm{km} \mathrm{14+100)}$ (Fig. 1). The Poprad river separates Beskid Sądecki into two parts: Radziejowa mountain and Jaworzyna mountain. Along the research area, on the left bank of the river there is a railway and the national road no 87 from Nowy Sącz to Piwniczna-Zdrój (Kobiela et al. 2012).

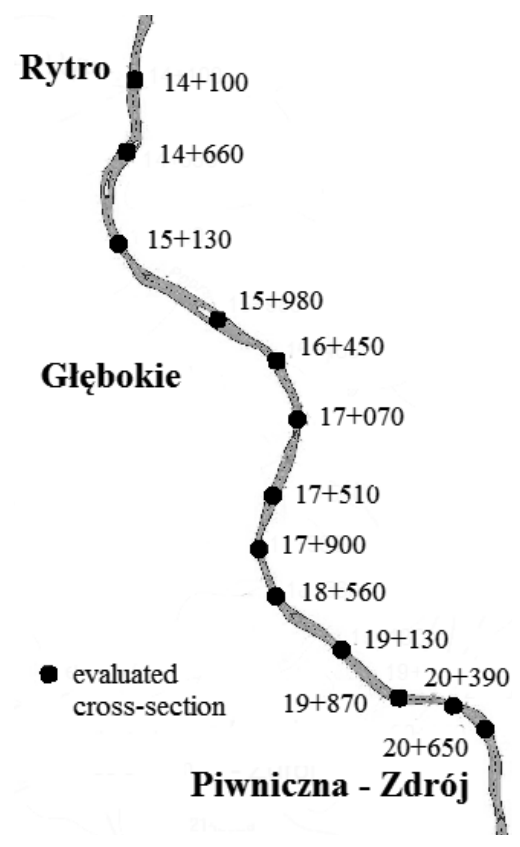

FIGURE 1. Resarch area of the Poprad river from Piwniczna - Zdrój (km 20+650) to Rytro $(\mathrm{km} \mathrm{14+100)}$ 
Hydromorphological valorization of evaluated cross-section on the Poprad river has been made according to the method of assessing the hydromorphological quality of the river (Wyżga et al. 2009, 2010, 2012, 2013). Ten features of channel, banks, riparian zone and floodplain area, which are specified in the standard PN-EN 14614 (CEN 2004) and modified by Wyżga et al. (2009, 2010, 2012, 2013), were assessed in all thirteen of the evaluated cross-sections.

Hydromorphological evaluation was executed during the research and on the basis of available information about each cross-section. Each features was evaluated on a scale from 1 - conditions similar to the natural, to 5 - extreme transformation. Then based on the average assessment of these features, the whole cross-section was classified as one of the five classes of hydromorphological quality of the river: high, good, moderate, poor, bad (Wyżga et al. 2009, 2010, 2012, 2013).

Landscape evaluation with ECOVAST method was also made on the research area. On the basis of this method 10 landscape features, which are associated with each other were assessed. These are (Spiegler and Dower 2006):

1) rocks (surface geology),

2) climate (hydrology, rivers, lakes, glaciers),

3) land form (geomorphology),

4) soil,

5) land cover (vegetation, wildlife, habitats),

6) characteristic features and patterns of agriculture and forestry,

7) characteristic features of houses and settlements,

8) other man-made features (e.g. industry, tourism, infrastructure),
9) historic features (e.g. castles, monasteries, archaeological sites),

10) feelings and associations.

Landscape valorization was also made during the field work and on the available data. First the complete research area was analyzed. Then the features influencing the character and assessment of the landscape were analyzed in each cross-section. The aim of the identification was to identify areas of considerable landscape diversity, the most valuable areas and areas which need improvement of landscape quality.

\section{RESULTS AND DISCUSSION}

The results of each category of features and hydromorphological quality class for the Poprad river were presented in Figure 2. The hydromorphological assessment shown considerable variability, mainly in features which describe banks, riparian zone and floodplain area.

Cross-section I (km 14+100) and cross-section XIII (km 20+650) were classified as the first class of hydromorphological quality on the river (high). It was considered that these cross-sections are slightly transformed by human (cross-section I is in Fig. 3). Cross-section III

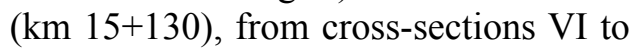
IX (from km 17+070 to $18+560$ ) and cross-section XII (km 20+390) belong to the second class of hydromorphological quality of the river (good). The third class of hydromorphological quality of the river (moderate) has been assigned to cross-sections II, IV, V and X (sequentially $\mathrm{km} 14+660,15+980,16+450$ and 19+130). Cross-section XI (km 19+870) was classified to the fourth class of hydromorphological quality of the river 


\begin{tabular}{|c|c|c|c|c|c|c|c|c|c|c|c|c|c|}
\hline \multirow{2}{*}{$\begin{array}{l}\text { Evaluated } \\
\text { cross-section }\end{array}$} & I & II & III & IV & $\mathrm{V}$ & VI & VII & VIII & IX & $\mathrm{X}$ & $\mathrm{XI}$ & XII & XIII \\
\hline & $14+100$ & +660 & $15+130$ & $5+980$ & $16+450$ & $17+070$ & $7+510$ & $17+900$ & $8+560$ & $19+130$ & $9+870$ & $20+390$ & $20+650$ \\
\hline \multicolumn{14}{|l|}{ Channel geometry } \\
\hline \multicolumn{14}{|l|}{ Substrate } \\
\hline \multicolumn{14}{|l|}{$\begin{array}{l}\text { In-river vegetation } \\
\text { and organic debris }\end{array}$} \\
\hline & & & & & & & & & & & & & \\
\hline \multicolumn{14}{|l|}{$\begin{array}{l}\text { Erosion/ deposition } \\
\text { character }\end{array}$} \\
\hline \multicolumn{14}{|l|}{ Flow } \\
\hline \multirow{2}{*}{\multicolumn{14}{|c|}{$\begin{array}{l}\text { Longitudinal river } \\
\text { continuity }\end{array}$}} \\
\hline & & & & & & & & & & & & & \\
\hline \multicolumn{14}{|l|}{ B ank structure } \\
\hline \multicolumn{14}{|l|}{$\begin{array}{l}\text { Vegetation/land use } \\
\text { in riparian zone }\end{array}$} \\
\hline \multicolumn{14}{|l|}{$\begin{array}{l}\text { Land use in } \\
\text { the river comidor }\end{array}$} \\
\hline $\begin{array}{l}\text { Lateral connectivity } \\
\text { channel migration }\end{array}$ & & & & & & & & & & & & & \\
\hline Average score & 1,60 & 2,60 & 1.95 & 3,00 & 2,90 & 2,30 & 2.25 & 2,40 & 2,25 & 2,60 & 3.50 & 2.20 & 1,60 \\
\hline
\end{tabular}

Key for hydromorphological quality dassification:

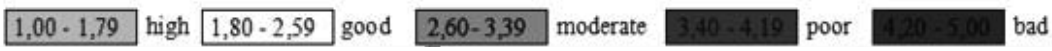

FIGURE 2. Evaluation of each hydromorphological features for I to XIII evaluated cross-section on the Poprad river with the average assessment made against the background of the classes of the hydromorphological quality

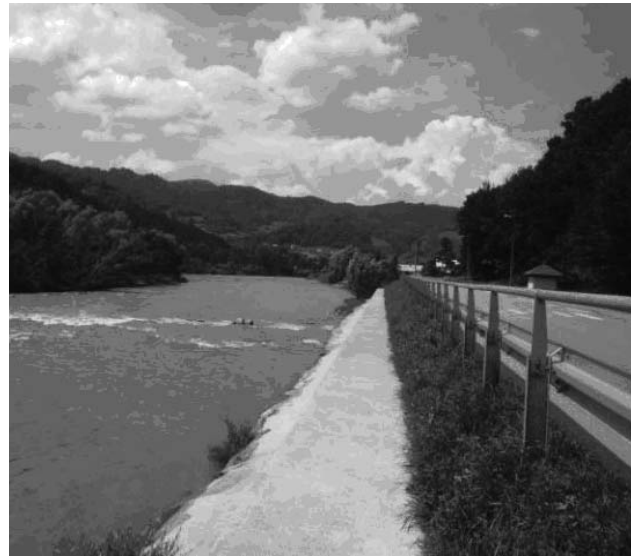

FIGURE 3. Concrete embankment as a strengthening of the right bank of the river - cross-section XI (km 19+870), (photo by M. Nawieśniak) (poor). This assessment is mainly due to strengthening of the right bank by a concrete embankment to approximately $3 \mathrm{~m}$ (Fig. 4). This strengthening was made to secure the road which is located in the immediate vicinity of the river channel. That entirely changed the character of the river bank, and interrupted the connection between the river and the floodplain area.

Based on assumptions of the ECOVAST method, the valley of the Poprad river from Piwniczna-Zdrój ( $\mathrm{km} \mathrm{20+650)}$ to Rytro $(\mathrm{km} \mathrm{14+100)}$ is distinguished by the characteristic landscape features shown in Table 1. 
TABLE 1. Landscape identification matrix for the evaluated section on the Poprad river between Piwniczna-Zdrój (km 20+650) and Rytro (km 14+100) based on ECOVAST method

\begin{tabular}{|c|c|}
\hline $\begin{array}{l}\text { Landscape features } \\
\text { ("Landscape layers") }\end{array}$ & $\begin{array}{l}\text { Relative strength of the features (graduation 1-4): } \\
\text { dominating, strong, moderate, low }\end{array}$ \\
\hline Feelings and associations & $\begin{array}{l}\text { dominating: mountain landscape, natural - small human interference, } \\
\text { low land use }\end{array}$ \\
\hline Historic features & $\begin{array}{l}\text { dominating: the ruins of the castle erected on the hill in Rytro, over the } \\
\text { right bank of the river (Fig. 4) }\end{array}$ \\
\hline Other man-made features & $\begin{array}{l}\text { strong: national road No } 87 \text { and railway along the river, on the left bank } \\
\text { of the river; concrete embankment as a strengthening of the right bank in } \\
\text { Piwniczna-Zdrój (Fig. 3) } \\
\text { moderate: raftsmen haven on the left bank of the river in Rytro; high } \\
\text { voltage electric poles in the vicinity of the right bank of the river in } \\
\text { Głębokie }\end{array}$ \\
\hline $\begin{array}{l}\text { Characteristic features } \\
\text { of houses and settlements }\end{array}$ & moderate: a single housing development along the river \\
\hline $\begin{array}{l}\text { Characteristic features } \\
\text { and patterns of agriculture }\end{array}$ & $\begin{array}{l}\text { low: meadow on a mountain slope on the right bank of the river in Rytro; } \\
\text { a single fields near the river (from Glębokie in the direction to Piwnicz- } \\
\text { na-Zdrój) }\end{array}$ \\
\hline Land cover & $\begin{array}{l}\text { dominating: mixed forests, which cover the mountain of Beskid } \\
\text { Sądecki }\end{array}$ \\
\hline Soil & $\begin{array}{l}\text { low: occurrence of podzolic soils with loess character and acid brown } \\
\text { soils }\end{array}$ \\
\hline Land form & dominating: mountain extending over the watershed of the Poprad river \\
\hline Climate & strong: mountain climate, occurrence of climate floors \\
\hline Rocks & $\begin{array}{l}\text { moderate: rocks outcrops (the Magura Nappe - Magura formation and } \\
\text { subunit Krynica) at the bank of the river in Rytro }\end{array}$ \\
\hline
\end{tabular}

Based on landscape values stocktaking and hydromorphological valorization results Authors had determined as follows.

Short description. Research area is located in Beskid Sądecki so the landscape has clearly mountain character. Makowica mountain (948 m a.s.1.), Skała mountain (773 m a.s.1.), Kamienny Groń mountain (791 m a.s.1.) or Kordowiec mountain (762 $\mathrm{m}$ a.s.1.) rising up along the Poprad river give a special landscape values to research area.

Assessment. The valley of the Poprad river is a distinct place in Beskid Sądecki. Mountains spread above the Poprad channel give regional importance to the area.
Additional comments. The valley of the Poprad river, as a whole, is an area of very high tourism potential, which is slightly transformed by human. However, in some cross-sections Authors recognized some elements which need to be improved in terms of the landscape quality, e.g. concrete embankment on the right bank of the river (Fig. 3). In addition to the elements which have negative impact on the landscape, research area is also characterized by very valuable elements.

In Table 2 cross-sections, which are classified in high or good class of hydromorphological quality in the river and also are characterized by valuable landscape value were presented. 
TABLE 2. Evaluated cross-section with high or good class of hydromorphological quality (according to Fig. 2) characterized by valuable landscape features

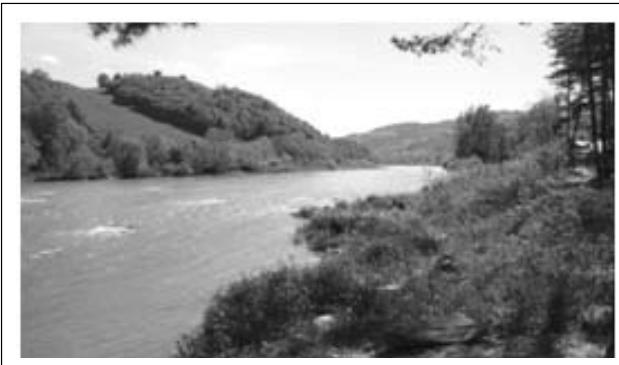

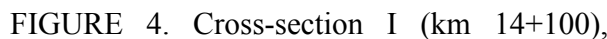
(photo by M. Nawieśniak)

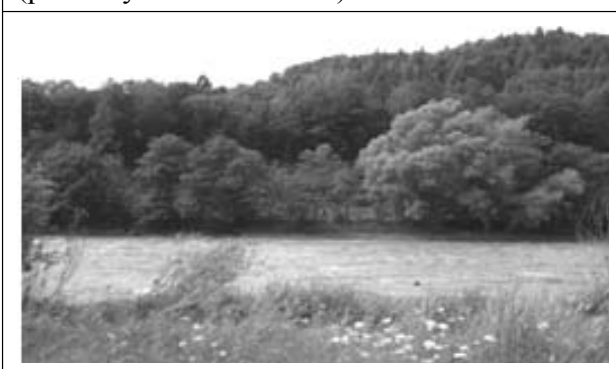

FIGURE 5. Cross-section III (km 15+130), (photo by M. Nawieśniak)

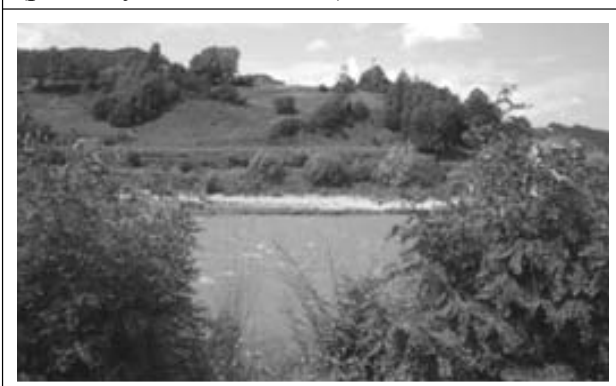

FIGURE 6. Cross-section VI (km 17+070), (photo by M. Nawieśniak)

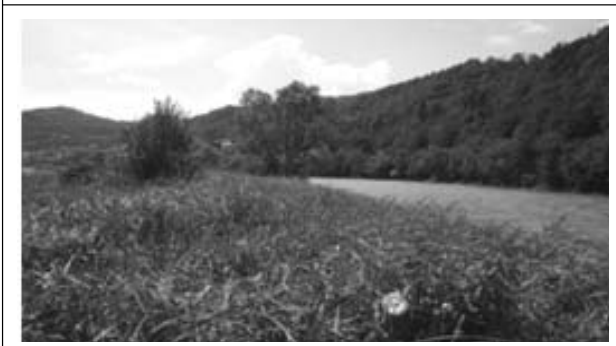

FIGURE 7. Cross-section VII $(\mathrm{km} 17+510)$, (photo by M. Nawieśniak)
From the point of view of hydromorphological assessment this cross-section was classified to first class of hydromorphological quality. There is a ruin of the castle which is located on the right bank of the river. This feature increases the value of the landscape in this cross-section. The area is slightly transformed by human

This cross-section was classified to second class of hydromorphological quality. Undeveloped area, the left bank of the river is covered with the trees and the right bank of the river is used for agriculture - meadows

This cross-section was classified to second class of hydromorphological quality. The area is also characterized by a high value of the landscape, but slightly protruding from the other sections due to the dominant influence of road in the immediate vicinity of the river channel

From the point of view of hydromorphological assessment this cross-section was classified to second class of hydromorphological quality. The area is slightly transformed by human; the right bank of the river is covered by trees, the left bank like in cross-section III - meadows 
TABLE 2 cont.

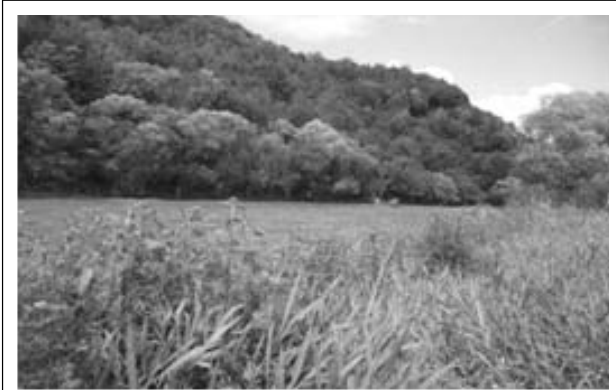

FIGURE 8. Cross-section VIII (km 17+900), (photo by M. Nawieśniak)

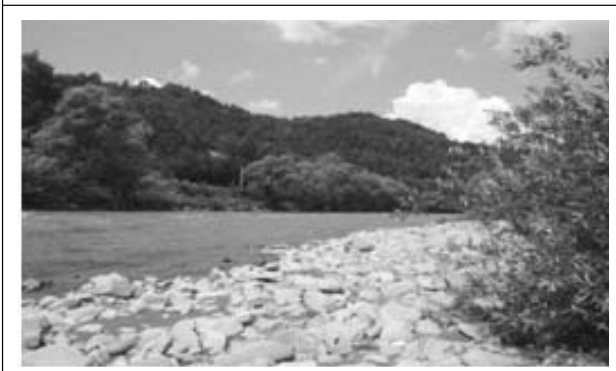

FIGURE 9. Cross-section IX (km 18+560), (photo by M. Nawieśniak)

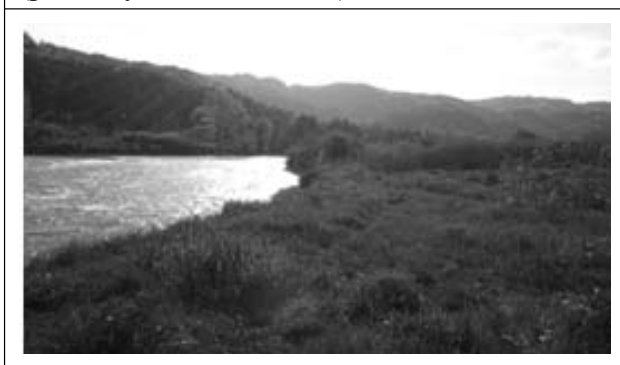

FIGURE 10. Cross-section XII (km 20+390), (photo by M. Nawieśniak)

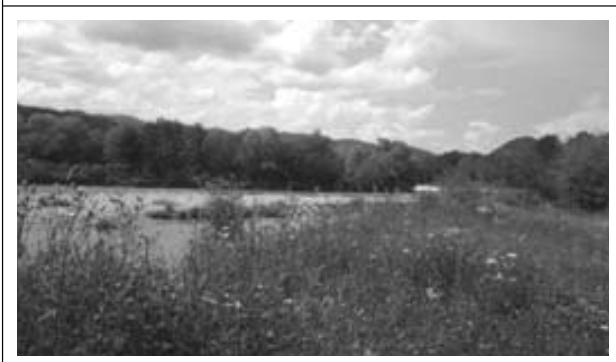

FIGURE 11. Cross-section XIII (km 20+650), photo by M. Nawieśniak)
Another cross-section was classified to second class of hydromorphological quality. The landscape value very similar to that in III and VII cross-section. Land cover: the right bank of the river - trees, and the left bank - meadows

This cross-section was classified to second class of hydromorphological quality. The left bank of the river has been strengthened, but in a way that does not affect the overall value of the landscape

From the point of view of hydromorphological assessment this cross-section was classified to second class of hydromorphological quality. Also, this cross-section has landscape values that provide high-value landscape of this area

The last cross-section and it was classified to first class of hydromorphological quality. In addition to high hydromorphological assessment of this area it is also characterized by high landscape value 
Changes in the landscape occur all the time and we are not able to stop them. We can only try to make the direction of these changes right (Spiegler et al. 2008). The basis of landscape management should be integrated management of the landscape especially with its own policy regarding spatial and urban planning. Very often in Polish municipalities, at the local level, the values and essence of the cultural landscape are underestimate. Very often that landscape loses with more urgent needs, both at the stage of forecasting, planning, as well as at the stage of implementation and execution (Hernik 2008).

The valleys of the river are characterized by very high landscape values, but very often we do not realize that even the simplest strengthening or technical treatments in the channel of the river affect the whole landscape of the valley.

Cultural landscapes will have a potential for local and regional development if they are properly considered in the broad sense of the environment and spatial planning (Linke and Hernik 2010). Wrong spatial management may pose large risk for landscape and cause underestimating and losing landscape potential.

The areas which are characterized by valuable landscape values should be remain unchanged and properly included in local land use plans. The research area is located in Popradzki Landscape Park, which suggests that this area actually has valuable landscape that should be protected.

Taking into account the hydromorphological and landscape valorization, it would seem that they are completely two different methods. However, after a closer analysis of these two methods we can conclude that they are complementary in the protection areas. Especially in the immediate vicinity of the river channel as the area which is the most attractive for tourism. To recognize a research area as a valuable, the results of both methods should be consistent.

\section{CONCLUSIONS}

The Poprad river in section from Piwniczna-Zdrój to Rytro is characterized by hydromorphological variability, mainly in relation to areas in the immediate vicinity of the river channel. This variability is due to smaller or larger human activities in these areas. At the same time the valley of the Poprad river is characterized by the landscape of regional importance, with a very large tourism potential.

Extended hydromorphological and landscape valorization on the research area allowed to identify valuable landscape areas. During the hydromorphological assessment, within the river channel and the areas adjacent to the channel anthropogenic transformed areas and areas without such transformations were determined. This is necessary for landscape assessment.

Executed landscape assessment in valley of the river should also take into account the features of the river channel, which have an impact on landscape values in whole river valley.

\section{Acknowledgments}

This research was financially supported by Ministry of Science and Higher Education in Poland in the framework of the project "The area management, protection and modelling of the environment 


\section{and landscape" DS 3371/KGPiAK/2015 and project BM4346/KiWIG/2014.}

\section{REFERENCES}

CEN 2004: Water quality - Guidance standard for assessing the hydromorphological features of rivers.

European Landscape Convention 2000. Adopted in Florence on 20 Oct. 2000 (Dz.U. 2006 nr 14, poz. 98$)$.

HERNIK J. 2008: Potrzeba uwzględniania walorów krajobrazu kulturowego w zarządzaniu gmina wiejską [Need for considering cultural landscape virtues in rural commune management]. Pr. Kom. Krajobr. Kultur. 10, 61-68 (Engl. summ.).

HERNIK J., GAWROŃSKI K., DIXON-GOUGH R. 2013: Social and economic conflicts between cultural landscapes and rural communities in the English and Polish systems. Land Use Policy 30, 800-813.

KAŁAMUCKA W. 2007: Ochrona dolin rzecznych $w$ systemie obszarów chronionych na przykładzie województwa lubelskiego [Protection of river valleys in the protected areas system on the example of lubelskie region]. Czasopismo Techniczne 7-A, 239-245 (Engl. summ.).

KOBIELA K., MOCZULSKI M., MUSZER D., POLUS M., ZARZYCKI J., ZAWORSKA-MATUGA W. 2012: Program ochrony środowiska dla powiatu nowosądeckiego na lata 2012-2015 z perspektywą do roku 2019 [The environmental program for nowosądecki region for the years 2012-2015 with the prospect for 2019]. Nowy Sącz (in Polish).

LINKE H.J., HERNIK J. 2010: Activities for the Protection of Historical Cultural Landscapes as a Supplementary Tool for Land Management with the Aim of the Development of Local and Regional Potential. Infrastr. Ekol. Ter. Wiejs. $11,71-81$.

SPIEGLER A., DOWER M. 2006: ECOVAST Landscape Identification - a guide to good practice (on-line access: www.ecovast.org).

SPIEGLER A., PIJANOWSKI J.M., HERNIK J. 2008: Landscape identification and evaluation research with the help of the ECOVAST method, as a contribution to the process of implementation of the European Landscape
Convention exemplified by the municipality of Wiśniowa. In: J.M. Pijanowski, J. Hernik (Eds) Cultural landscape protecting historical cultural landscapes to strengthen regional identities and local economies. Infrastr. Ekol. Ter. Wiejs., Monograph 12, 28-42.

STOEGLEHNER G., SCHMID J. 2007: Development of cultural landscapes - Austrian situation and future perspective in the light of the ELC. In: J. Hernik, J.M. Pijanowski (Eds) Cultural Landscape - Assessment, Protection, Shaping. Wyd. AR, Kraków, 59-67.

WFD 2000: Directive 2000/60/EC of the European Parliament and the Council of 23 Oct. 2000 establishing a Framework for Community action in the field of water policy.

WIŚNIOWSKA-WĘGLARZ R. 2008: Sieć hydrograficzna ziemi muszyńskiej. Z cyklu Rzeki Sądecczyzny. Cz. I. [The hydrographic network of Muszyna. From the series The Rivers of Sądeczcyzna. Part I]. Almanach Muszyny, 217-222 (on-line access: www.almanachmuszyny.pl).

WYŻGA B., AMIROWICZ A., RADECKI-PAWLIK A., ZAWIEJSKA J. 2009: Hydromorphological conditions, potential fish habitats, and the fish community in a mountain river subjected to variable human impacts, the Czarny Dunajec, Polish Carpathians. River Research and Applications 25, 517-536.

WYŻGA B., ZAWIEJSKA J., RADECKI-PAWLIKA.,AMIROWICZA. 2010: A method for the assessment of hydromorphological river quality and its application to the Czarny Dunajec, Poilsh Carpathians. In: A. Radecki-Pawlik, J. Hernik (Eds) Cultural Landscapes of River Valleys. Wyd. UR, Kraków, 145-164.

WYŻGA B., ZAWIEJSKA J., RADECKI-PAWLIK A., HAJDUKIEWICZ H. 2012: Environmental change, hydromorphological reference conditions and the restoration of Polish Carpathians rivers. Earth Surface Processes and Landforms 37, 1213-1226.

WYŻGA B., ZAWIEJSKA J., RADECKI-PAWLIK A., HAJDUKIEWICZ H. 2013: Ustalenie hydromorfologicznych warunków referencyjnych dla rewitalizacji rzek w kontekście zmian środowiskowych w zlewniach [Environmental change, hydromorphological reference conditions and the restoration of Polish Carpathian rivers]. In: B. Wyżga (Ed.) Stan środowiska 
rzek południowej Polski - znaczenie środowiskowe, degradacja i możliwości rewitalizacji rzek wielonurtowych. Instytut Ochrony Przyrody PAN, Kraków, 59-86 (Engl. summ.).

Streszczenie: Hydromorfologiczna i krajobrazowa waloryzacja doliny rzeki Poprad. Artykuł przedstawia wyniki hydromorfologicznej oraz krajobrazowej oceny doliny rzeki Poprad, na odcinku od Piwnicznej-Zdrój do miejscowości Rytro (województwo małopolskie). Waloryzację hydromorfologiczną przeprowadzono metodą oceny hydromorfologicznej jakości rzeki, a waloryzację krajobrazową wykonano metodą ECOVAST. Na podstawie przeprowadzonych badań stwierdzono, że obszar badawczy charakteryzuje się znaczna zmiennością hydromorfologiczną, w szczególności w odniesieniu do teras zalewowych $\mathrm{i}$ ich łączności z korytem głównym cieku. Jednocześnie dolina rzeki Poprad charakteryzuje się krajobrazem o znaczeniu regionalnym, $\mathrm{z}$ bardzo dużym potencjałem turystycznym.
Stowa kluczowe: waloryzacja hydromorfologiczna, metoda ECOVAST, identyfikacja krajobrazu, dolina rzeki Poprad

\section{MS received November 2015}

\section{Authors' addresses:}

Maria Nawieśniak, Józef Hernik

Katedra Gospodarki Przestrzennej i Architektury

Krajobrazu

Uniwersytet Rolniczy w Krakowie ul. Balicka 253c, 30-149 Kraków

Poland

e-mail: m.nawiesniak@ur.krakow.pl rmhernik@cyf-kr.edu.pl

\section{Mateusz Strutyński}

Katedra Inżynierii Wodnej i Geotechniki

Uniwersytet Rolniczy w Krakowie

al. A. Mickiewicza 24/28, 30-059 Kraków

Poland

e-mail: mstrutynski@ar.krakow.pl 